\title{
A note on government, society and terminology
}

In October 1968, the Republic was governed by Fianna Fáil, who had been in power since 1957. The Taoiseach was Jack Lynch. In the election of June 1969, Fianna Fáil were returned with a majority. This administration was faced with the crisis of August 1969 and the resulting Arms Trial which brought the North centre stage for a period, as did Bloody Sunday in early 1972. In February 1973, a Fine Gael/Labour coalition, with Liam Cosgrave as Taoiseach, took power. Cosgrave's cabinet included Conor Cruise O’Brien, Paddy Donegan and Patrick Cooney, all implacable opponents of the IRA. The Coalition was associated in the public mind with a hard line against republicanism.

In 1977, Fianna Fáil won a shock overall majority, with over one million votes and 84 Dáil seats. In 1979, Jack Lynch resigned and was replaced as Taoiseach by Charles J. Haughey, who was popularly associated with a republican stance on the North.

The population of the Republic was 3,192,000 in 1977 and was growing and becoming younger. That year's election was the first time all those over 18 years of age could vote. Over $96 \%$ of the state's people were Catholic. Around 30\% of the population lived in Dublin and its environs, while the number of people living in towns outnumbered that in rural areas for the first time during the 1970s. Over a quarter of the workforce were employed in agriculture, forestry or fishing at the beginning of the 1970 s, while $30 \%$ worked in manufacturing and $43.5 \%$ in services. In 1973, over half of the Republic's imports and exports were with the United Kingdom. ${ }^{1}$

\section{Terminology}

Northern Ireland was often referred to as 'the North' or (by nationalists) as the 'Six Counties'. While the term 'Northern Ireland' itself implied recognition 
of that state and was therefore eschewed by republicans, by the 1970s it had become part of official discourse in the Republic of Ireland. The Republic was sometimes described by supporters of the IRA (and those from the North more generally) as the 'Free State' and by many people as the '26 Counties', or the south.

The republican movement had split between 1969 and 1970 into Official and Provisional organizations ('Stickies' and 'Provos'). In May 1972, the Official IRA declared a ceasefire (though it did not cease armed activity) and by the mid 1970s the main political focus, north and south, was on the Provisionals. For the sake of brevity in the text, where the Officials are concerned I signal that, but on other occasions 'Sinn Féin' and 'IRA' refer to the Provisionals.

\section{Notes}

1 Basil Chubb, 'Society and the Political System' in Penniman, H. (Ed.) Ireland at the Polls: the 1977 Dáil Elections (Washington D.C., 1978) pp. 1-20.

2 For a fuller discussion of the Officials, see B. Hanley and S. Millar, The Lost Revolution: The Story of the Official IRA and the Workers' Party (Dublin, 2010). 
Brian Hanley - 9781526131621 